\title{
Intraductal Glycogen-Rich Clear Cell Carcinoma of the Breast: A Rare Presentation and Review of the Literature
}

\author{
Nikolaos S. Salemis \\ Breast Surgery Unit, Army General Hospital, Athens, Greece
}

Keywords

Clear cell breast carcinoma: glycogen-rich, intraductal

\begin{abstract}
Summary
Background: Glycogen-rich clear cell carcinoma of the breast is a rare histological subtype of breast cancer, accounting for $0.9-2.8 \%$ of all breast cancer cases. Fewer than 100 cases have been reported in the literature. Most of these tumors are invasive carcinomas. The intraductal glycogen-rich clear cell carcinoma is a very rare occurrence. Case Report: Herein is described a case of a pure intraductal glycogen-rich clear cell carcinoma of the breast in a 42-year-old premenopausal woman. A literature review has also been carried out. Mammography was inconclusive due to the presence of dense breast tissue, but magnetic resonance imaging (MRI) showed several nodular lesions measuring $7 \times 6 \mathrm{~cm}$ in diameter and involving the upper aspect of the right breast suggestive of multifocal malignancy. A modified radical mastectomy was performed. The patient started hormonal therapy with tamoxifen and is currently well 16 months after surgery. Conclusion: A pure intraductal glycogen-rich clear cell carcinoma of the breast is a very rare occurrence. The case presented here exhibited uncommon MRI features, whereas the tumor size is one of the largest reported in the literature. Mammography may be inconclusive in the presence of dense breast tissue, but MRI is of great importance in the preoperative evaluation of the patient.
\end{abstract}

\section{Schlüsselwörter \\ Klarzelliges Mammakarzinom: glykogenreich, intraduktal}

\section{Zusammenfassung}

Hintergrund: Das glykogenreiche, klarzellige Mammakarzinom ist ein seltener histologischer Subtyp (0,9-2,8\% aller Mammakarzinome). Weniger als 100 Fälle sind bisher in der Literatur beschrieben worden. Die meisten dieser Tumoren sind invasive Karzinome. Das intraduktale, glykogenreiche, klarzellige Karzinom ist dagegen äußerst selten. Fallbericht: Wir stellen hiermit einen Fall von reinem intraduktalen, glykogenreichen, klarzelligen Mammakarzinom bei einer 42-jährigen, prämenopausalen Patientin vor. Des Weiteren wird ein Überblick über die Literatur gegeben. Die mammographische Untersuchung erbrachte auf Grund des Vorliegens von dichtem Brustgewebe keine schlüssigen Ergebnisse. Die Magnetresonanztomographie (MRT) zeigte dagegen mehrere noduläre Läsionen $(7 \times 6 \mathrm{~cm}$ im Durchmesser) im oberen Bereich der rechten Brust, was auf eine multifokale Tumorerkrankung schließen ließ. Nach modifizierter radikaler Mastektomie wurde die Hormontherapie mit Tamoxifen begonnen, und die Patientin ist 16 Monate nach Operation in gutem gesundheitlichen Zustand. Schlussfolgerung: Ein reines intraduktales, glykogenreiches, klarzelliges Mammakarzinom ist sehr selten. Der hier vorgestellte Fall zeigte ein ungewöhnliches Erscheinungsbild im MRT, und die Tumorgröße ist die bisher umfangreichste in der Literatur. Die mammographische Untersuchung kann bei Vorliegen von dichtem Brustgewebe uneindeutige Ergebnisse erbringen. Das MRT ist dagegen von großer Wichtigkeit für die präoperative Evaluierung des Patienten.

\section{KARGER \\ Fax +497614520714 \\ Information@Karger.de}

www.karger.com (c) 2012 S. Karger GmbH, Freiburg

$1661-3791 / 12 / 0074-0319 \$ 38.00 / 0$

Accessible online at:

www.karger.com/brc
Nikolaos S. Salemis, MD, PhD

Breast Surgery Unit

19 Taxiarhon Str, 19014 Kapandriti, Athens, Greece

Tel. +30 22950 23559, Mobile +30 6932528444

nikos_salemis@hotmail.com 


\section{Introduction}

Glycogen-rich clear cell carcinoma (GRCCC) of the breast is a rare histological subtype of breast cancer, accounting for $0.9-2.8 \%$ of all breast cancer cases [1-5]. Its morphological characteristics are different from those of conventional breast carcinomas but the tumor shares some common features with clear cell carcinomas arising in other organs [6]. Histologically, the tumor is characterized by the presence of abundant clear cell cytoplasm containing periodic acid-Schiff (PAS)positive, diastase-labile glycogen in more than $90 \%$ of the neoplastic cells [7]. Fewer than 100 cases of GRCCC have been reported in the literature [8]. Mastectomy and axillary dissection is the treatment performed in the majority of cases, whereas $30 \%$ of the patients have axillary nodal metastases $[1,9]$. In most cases the tumor exhibits an infiltrative growth pattern. Intraductal tumors are very rare.

\section{Case Report}

A 42-year-old premenopausal woman presented at our breast clinic with a lump in her right breast, which she had first noticed a week ago. On clinical examination an irregular hard lump measuring approximately $1 \times 2 \mathrm{~cm}$ was barely palpable in the upper outer quadrant of her right breast; enlarged lymph nodes were palpable in the right axilla. Mammography was inconclusive in the presence of dense breast tissue, and she was assessed as BI-RADS category 0 . A hardly visible isolated cluster of microcalcifications was observed in the upper outer quadrant of the right breast. An ultrasound scan revealed the presence of 3 hypoechoic nodules with irregular borders and posterior acoustic enhancement. In addition, 3 other nodules were detected which exhibited benign ultrasound

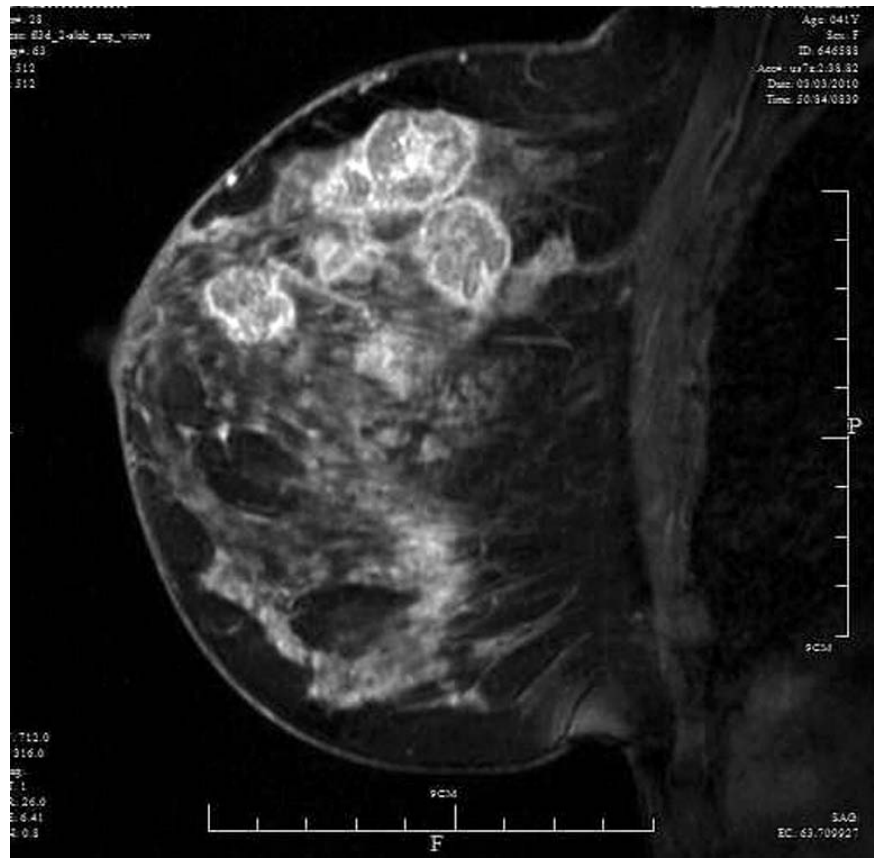

Fig. 1. Sagittal contrast-enhanced T1-weighted magnetic resonance image showing multiple enhancing lesions involving the upper right breast suggestive of multifocal malignancy.
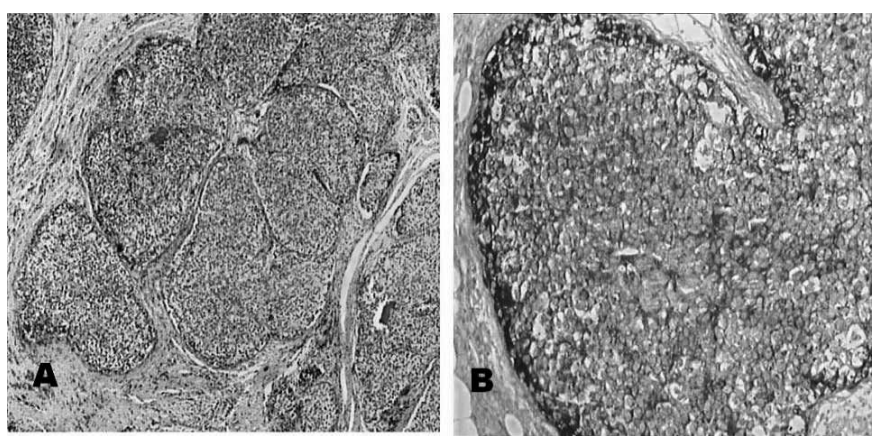

Fig. 2. A. Histology shows an intraductal carcinoma with a solid growth pattern composed of cells with clear cytoplasm and small dark punctuate nuclei $(H \& E$ stain, $\times 25)$. B. The tumor is periodic acid-Schiff-positive (PAS stain, $\times 100)$.

features. A breast magnetic resonance imaging (MRI) scan was obtained which revealed at least 6 lesions ranging in diameter from 1 to $3 \mathrm{~cm}$ and involving the upper aspect of the right breast suggestive of multifocal malignancy (fig. 1). Core needle biopsy was not performed preoperatively because of the patient's preference. Frozen section confirmed the presence of malignancy, and a right modified radical mastectomy was performed. Histology revealed an intraductal carcinoma with a solid growth pattern composed of cells with clear cytoplasm and small dark punctuate nuclei (fig. 2 A). In addition, areas of comedo-type necrosis and cribiform growth pattern were found. On histochemical examination, the tumor cells stained positive with the PAS reaction (fig. 2 B). Stains were however digested with diastase. The tumor cells stained positive for estrogen receptors (ER) and progesterone receptors (PR), 100 and 90\% respectively. All 19 resected lymph nodes, measuring up to $2 \mathrm{~cm}$, were free of metastases, with signs of non-specific reactive lymphadenopathy. Finally, a fibroadenoma measuring $1.8 \mathrm{~cm}$ in diameter was found in the mastectomy specimen. No other nodular lesion was described in the pathology report. The patient was started on tamoxifen and is currently well 16 months after surgery.

\section{Discussion}

The first case of GRCCC of the breast was reported by Hull et al. [10] in 1981. The tumor most commonly affects women in the 5 th decade of life $[1,7-9]$. Patients usually present with a mass that may be accompanied by skin dimpling, nipple retraction, or pain. Tumors range in diameter from 1 to $6.5 \mathrm{~cm}$, whereas the largest reported mass measured $10 \mathrm{~cm}$ in diameter [1,9]. The tumor may be present from 2 months to 2 years before a clinical diagnosis is made [11]. Histologically, the tumor cells tend to have sharply defined borders and polygonal contours [7], often form invasive nests, cords or papillary structures, and may be associated with an intraductal component [12]. Very rare cases of GRCCC with neuroendocrine differentiation have been reported [13]. The intraductal growth pattern of GRCCC is a very rare occurrence. Out of 20 cases of GRCCC reported by Kuroda et al. [1], only 1 was of a non-invasive pattern. Fisher et al. [14] reported 45 cases of GRCCC, $78 \%$ of which were invasive ductal carcinomas, $11 \%$ were invasive lobular carcinomas, $7 \%$ had com- 
bined ductal and lobular features, $2 \%$ were tubular, and $2 \%$ were medullary carcinomas. No intraductal tumors were reported in that study. Intraductal GRCCCs are most commonly small tumors measuring $0.4-1.5 \mathrm{~cm}$ in diameter and are usually non-comedo carcinomas [5]. Cytological diagnosis of GRCCC is difficult based only on morphological features [15]. The tumor most likely to be confused with GRCCC is high-grade invasive ductal carcinoma $[11,16]$. Differential diagnosis of GRCCC includes secretory carcinoma, lipid-rich carcinoma, apocrine carcinoma, and mucinus carcinoma [12]. Clear cell carcinoma may also arise in other organs such as lung, endometrium, salivary gland, ovary, and cervix [1, 3, 6, 17]. Thorough investigation is essential to rule out a metastatic clear cell carcinoma to the breast, especially from renal cell carcinoma [11,17]. There are insufficient published data about the imaging characteristics of GRCCC [12, 17]. The mammogram may be inconclusive due to dense breast tissue [17], and the tumor may have benign characteristics on mammography [18]. Some authors have suggested that GRCCC is associated with an aggressive clinical course [2, 3] compared to conventional ductal carcinoma. The clinical course of patients with GRCCC may vary depending on histological characteristics such as low grade and positive ER expression [18]. Further studies are however needed to better determine the behavior and prognosis of GRCCC $[1,17]$.

\section{Conclusion}

Intraductal GRCCC of the breast is a very rare occurrence. The reported case featuring multifocal disease is one of the largest intraductal GRCCCs reported in the literature. Mammography may be inconclusive in the presence of dense breast tissue, but MRI is of great importance in the preoperative evaluation of the patient.

\section{Disclosure Statement}

There are no conflicts of interest.

\section{References}

1 Kuroda H, Sakamoto G, Ohnisi K, Itoyama S: Clinical and pathological features of glycogen-rich clear cell carcinoma of the breast. Breast Cancer 2005;12:189-195.

2 Toikkanen S, Joensuu H: Glycogen-rich clear-cell carcinoma of the breast: a clinicopathologic and flow cytometric study. Hum Pathol 1991;22:81-83.

3 Hull MT, Warfel KA: Glycogen-rich clear cell carcinomas of the breast. A clinicopathologic and ultrastructural study. Am J Surg Pathol 1986; 10:553-559.

4 Satake N, Uehara H, Sano N, Kubo T, Sasa M, Izumi K: Cytological analysis of glycogen-rich carcinoma of the breast: report of two cases. J Med Invest 2002;49:193-196.

5 Hayes MM, Seidman JD, Ashton MA: Glycogenrich clear cell carcinoma of the breast. A clinicopathologic study of 21 cases. Am J Surg Pathol 1995;19:904-911.

6 Gürbüz Y, Ozkara SK: Clear cell carcinoma of the breast with solid papillary pattern: a case report with immunohistochemical profile. J Clin Pathol 2003;56:552-554.
7 Tavassoli FA, Devilee P (eds): World Health Organization Classification of Tumors: Pathology and Genetics of Tumors of the Breast and Female Genital Organs. Lyon, France, IARC Press, 2003.

8 Yerushalmi R, Hayes MM, Gelmon KA: Breast carcinoma - rare types: review of the literature. Ann Oncol 2009;20:1763-1770.

9 Rosen PP: Glycogen rich carcinoma; in Rosen PP (ed): Rosen's Breast Pathology, 3rd ed. Philadelphia, PA, Lippincott Williams and Wilkins, 2008, pp. 612-615.

10 Hull MT, Priest JB, Broadie TA, Ransburg RC, McCarthy LJ: Glycogen-rich clear cell carcinoma of the breast: a light and electron microscopic study. Cancer 1981;48:2003-2009.

11 Akbulut M, Zekioglu O, Kapkac M, Erhan Y, Ozdemir N: Fine needle aspiration cytology of glycogen-rich clear cell carcinoma of the breast: review of 37 cases with histologic correlation. Acta Cytol 2008;52:65-71.

12 Trupiano JK, Ogrodowczyk E, Bergman S: Pathologic quiz case: mass in the right breast. Glycogenrich clear cell carcinoma of the breast. Arch Pathol Lab Med 2003;127:1629-1630.
13 Di Tommaso L, Pasquinelli G, Portincasa G, Santini D: Glycogen-rich clear-cell breast carcinoma with neuroendocrine differentiation features. Pathologica 2001;93:676-680.

14 Fisher ER, Tavares J, Bulatao IS, Sass R, Fisher B: Glycogen-rich, clear cell breast cancer: with comments concerning other clear cell variants. Hum Pathol 1985;16:1085-1090.

15 Das AK, Verma K, Aron M: Fine-needle aspiration cytology of glycogen-rich carcinoma of breast: report of a case and review of literature. Diagn Cytopathol 2005;33:263-267.

16 Kern SB, Andera L: Cytology of glycogen-rich (clear cell) carcinoma of the breast. A report of two cases. Acta Cytol 1997;41:556-560.

17 Mizukami Y, Takayama T, Takemura A, Ichikawa K, Onoguchi M, Taniya T: Glycogen-rich clear cell carcinoma of the breast: a case report. J Med Ultrasonics 2009:36:39-43.

18 Markopoulos C, Mantas D, Philipidis T, Kouskos E, Antonopoulou Z, Hatzinikolaou M, Gogas H: Glycogen-rich clear cell carcinoma of the breast. World J Surg Oncol 2008;6:44. 